\title{
PENGEMBANGAN MODEL FIDUSIA TERHADAP PENITIPAN BARANG DARI PERSERO PEGADAIAN KEPADA DEBITUR
}

\section{DEVELOPMENT OF FIDUSIA MODELS ON DEPOSIT COUNTER FROM PT PEGADAIAN PERSERO TO THE DEBTOR}

\author{
M. Taufich Hidayat, \\ Martin Roestamy, dan \\ Endeh Suhartini
}

\author{
Program Studi Hukum, Sekolah Pascasarjana, \\ Universitas Djuanda Bogor. \\ Korespondensi : M. Taufich Hidayat, Telp. - \\ e-mail : moch.taufich@unida.ac.id
}

Jurnal Living Law, Vol. 11, No. 2, 2019

hlm. 160171

\begin{abstract}
This study aims: 1) To find out and analyze the development of fiduciary models for safekeeping of goods from PT. Pegadaian to the debtor, 2) To find out and analyze the execution of fiduciary guarantees at PT. Pegadaian if the debtor defaults. The research method used in this study is a normative juridical study that uses a qualitative approach. The results of this study are: 1) Development of the fiduciary model for safekeeping of goods from the PT. Pegadaian to the debtor, namely the Fiduciary Installment Credit System (KREASI), where the credit facility is subject to the provisions applicable to fiduciary law. Debtors who need funds do not hand over objects used as collateral to PT. Pegadaian as a creditor. 2) Execution of fiduciary guarantees at PT. Pegadaian if the debtor defaults, in the execution of fiduciary guarantees at PT. Pegadaian there are differences of opinion between PT. Pegadaian with the State Receivables and Auction Service Office (KP2LN). PT. Pegadaian states that the execution of fiduciary guarantees is carried out on its own with reference to the Basic Rules of PT. Pegadaian. Whereas KP2LN believes that the one authorized to carry out fiduciary guarantees is KP2LN with reference to the Fiduciary Law. In this case the author agrees with KP2LN because the legal basis of the Fiduciary Law is stronger than the Basic Rules of PT. Pegadaian.
\end{abstract}

Keywords : Deposit Services, Fiduciary Model, PT. Pegadaian

\begin{abstract}
Abstrak : Penelitian ini bertujuan: 1) Untuk mengetahui dan menganalisis pengembangan model fidusia terhadap penitipan barang dari persero pegadaian kepada debitur, 2) Untuk mengetahui dan menganalisis eksekusi jaminan fidusia di PT. Pegadaian apabila debitur wanprestasi. Metode penelitian yang digunakan dalam penelitian ini adalah penelitian yuridis normatif yang melakukan pendekatan kualitatif. Hasil dari penelitian ini yaitu: 1) Pengembangan model fidusia terhadap penitipan barang dari persero pegadaian kepada debitur, yaitu dengan Kredit Angsuran Sistem Fidusia (KREASI), dimana pada fasilitas kredit tersebut tunduk pada ketentuan yang berlaku pada hukum fidusia. Debitur yang membutuhkan dana tidak menyerahkan benda yang dijadikan agunan kepada PT. Pegadaian sebagai kreditur. 2) Eksekusi jaminan fidusia di PT. Pegadaian apabila debitur wanprestasi, dalam pelaksanaan eksekusi jaminan fidusia di PT. Pegadaian ada perbedaan pendapat antara PT. Pegadaian dengan Kantor Pelayanan Piutang dan Lelang Negara (KP2LN). PT. Pegadaian menyatakan bahwa eksekusi jaminan fidusia dilakukan sendiri dengan mengacu pada Aturan Dasar Pegadaian. Sedangkan KP2LN berpendapat bahwa yang berwenang untuk melaksanakan eksekusi jaminan fidusia adalah KP2LN dengan mengacu pada UU Fidusia. Dalam hal ini penulis lebih sependapat dengan KP2LN karena dasar hukumnya yaitu UU Fidusia lebih kuat dibandingkan dengan Aturan Dasar Pegadaian.
\end{abstract}




\section{PENDAHULUAN}

Perkembangan ekonomi saat sekarang mengalami peningkatan yang sangat pesat. Banyak sektor usaha berlomba-lomba untuk menarik simpati masyarakat dalam menyediakan jasa pembiayaan. Seperti halnya lembaga keuangan bank dan lembaga keuangan bukan bank semakin jeli melihat kebutuhan manusia untuk mencari peluang usaha. Mengenai kebutuhan manusia dimaksud dapat dilogika 3 (tiga) macam, yaitu kebutuhan primer, sekunder dan tersier. ${ }^{1}$

Kemajuan suatu negara membawa dampak positif dalam bidang perekonomian negara tersebut. Tetapi dampak positif perekonomian bagi negara belum tentu membawa dampak positif pula bagi masyarakatnya. Seiring dengan majunya suatu negara dan perekonomiannya, besar pula kebutuhan hidup yang harus dipenuhi oleh masyarakat. Kebutuhan hidup manusia pada era globalisasi ini sangat besar. Apalagi dalam memenuhi kebutuhan hidupnya manusia harus bekerja dengan giat. Di Indonesia banyak masyarakat yang sukses dalam pekerjaannya sehingga mampu untuk memenuhi kebutuhan hidup, akan tetapi tidak semua masyarakat bisa sukses dalam pekerjaannya sehingga apabila tidak mampu untuk memenuhi kebutuhan hidupnya masyarakat harus mencari upaya lain seperti misalnya menjual barang berharga yang mereka miliki. Dengan dijualnya barang berharga maka masyarakat akan mendapatkan sejumlah uang yang bisa dipakai untuk memenuhi kebutuhan. Tetapi dengan dijualnya barang berharga resiko yang ditimbulkan adalah tidak bisa untuk diperoleh kembali barang tersebut karena sudah beralih tangan dan menjadi hak milik orang lain.

Upaya pemerintah dalam menghadapi tantangan era globalisasi memerlukan

1 Gatot Supramono, Perjanjian Utang Piutang, Jakarta: Kencana Prenada Media Group, 2013, Hlm. 1. berbagai langkah alternatif yang bertujuan untuk memberikan kontribusi menjawab tantangan perekonomian ke depan. Salah satunya adalah mengupayakan supaya produk Indonesia dapat bersaing dengan produk luar yang masuk Indonesia ataupun di pasar internasional. Menghadapi kendala tersebut, pemerintah harus bekerja keras untuk menangani kondisi ini dengan cepat, disertai dengan semangat dan dukungan masyarakat untuk mencari jalan keluar dari krisis ekonomi sehingga mampu meningkatkan efisiensi ekonomi. Dalam konteks tersebut langkah alternatif yang dapat ditempuh di antaranya adalah memaksimalkan peran Badan Usaha Milik Negara (BUMN) melalui format baru yang efisien. BUMN di Indonesia bergerak hampir di seluruh aspek ekonomi. Kemampuan BUMN untuk menjadi penggerak efisiensi nasional sangat diharapkan sehingga peran sebagai agen pembangunan dapat tercapai.

Perubahan status badan hukum Pegadaian dari Perum ke Perseroan Terbatas diharapkan dapat memacu dan memicu kinerja pegadaian lebih ekspansif lagi serta menjadi jalan untuk menawarkan saham kepada publik sehingga kemampuan permodalan yang dimiliki pegadaian lebih kuat dan lebih besar lagi untuk melayani nasabahnya. ${ }^{2}$

Dalam era perdagangan bebas dan meningkatnya kebutuhan masyarakat, masalah daya saing dan keunggulan saing merupakan isu kunci dan sekaligus tantangan yang berat. Banyak hal yang dilakukan oleh masyarakat untuk memenuhi kebutuhannya yang semakin hari semakin meningkat. Namun adakalanya penghasilan yang didapat dari bekerja masih kurang dan tidak dapat menutupi kebutuhan akan sejumlah uang terutama di saat-saat mendesak atau tidak terduga yang harus segera dipenuhi dalam waktu yang singkat. Untuk mengatasi masalah tersebut salah satu cara yang dapat ditempuh yaitu dengan melalui

\footnotetext{
2 Warta Pegadaian, Edisi 160/Tahun xxiii/2017.
} 
hutang-piutang di lembaga pembiayaan baik bank maupun non bank. Kegiatankegiatan demikian sering dilakukan oleh Warga Negara Indonesia pada umumnya, karena sudah menjadi kebutuhan rakyat, yang akhirnya membutuhkan fasilitas kredit dalam usahanya. ${ }^{3}$ Dengan adanya perkreditan tersebut, timbullah hubungan hutang-piutang antara para pihak, yaitu pihak kreditur dan debitur. Dengan usaha ini, pemerintah melindungi rakyat kecil yang tidak mempunyai akses ke dalam perbankan dan melindungi masyarakat dari pinjaman tidak wajar.

Hubungan hutang piutang antara debitur dengan kreditur sering disertai dengan jaminan. Jaminan itu dapat berupa uang dan dapat pula berupa orang. Dalam hal ini yang akan dibicarakan adalah hubungan hutang piutang dengan jaminan benda. Dengan adanya jaminan ini, kreditur mempunyai hak atas benda jaminan untuk pelunasan piutangnya apabila debitur tidak membayar hutangnya. Benda jaminan itu bisa berupa benda bergerak dan dapat pula berupa benda tidak bergerak. Apabila benda jaminan itu berupa benda bergerak, maka hak atas benda jaminan itu disebut "gadai".4

Sedangkan pengertian gadai menurut H. Salim HS. adalah "suatu perjanjian yang dibuat antara kreditur dengan debitur, dimana debitur menyerahkan benda bergerak kepada kreditur, untuk menjamin pelunasan suatu hutang gadai, ketika debitur lalai melaksanakan prestasinya". 5 Lembaga keuangan di Indonesia dapat dibagi menjadi Lembaga Keuangan Bank dan Lembaga Keuangan Non Bank. Pegadaian merupakan salah satu Lembaga Keuangan Non Bank di Indonesia yang membantu masyarakat dalam hal gadai. Adanya lembaga tersebut memudahkan

3 Purwahid Patrik dan Kashadi, Hukum Jaminan Edisi Revisi Dengan UUHT, Pusat Studi Hukum Perdata dan Pembangunan Fakultas Hukum Universitas Diponegoro, Semarang, 1993, Hlm. 1.

4 Abdul Kadir Muhammad, Hukum Perdata Indonesia, Bandung: PT. Citra Aditya Bakti, 2000, Hlm. 170.

${ }^{5}$ H. Salim HS., Op.Cit, HIm. 34. masyarakat dalam memperoleh uang dengan cepat dan proses yang mudah tanpa harus kehilangan barangnya. Sebelum beralih status hukumnya menjadi Perseroan Terbatas (PT), Pegadaian merupakan lembaga yang berbentuk Badan Usaha Milik Negara (BUMN). BUMN merupakan salah satu pelaku ekonomi dalam perekonomian nasional yang berlandaskan demokrasi ekonomi, memiliki peranan penting dalam penyelenggaraan perekonomian nasional dalam mewujudkan kesejahteraan masyarakat.

Masyarakat yang menggadaikan barang berharga miliknya di pegadaian akan mendapatkan bukti berupa Surat Bukti Kredit (SBK) dan mereka akan menerima uang. Bagi masyarakat yang menggadaikan barangnya di pegadaian maka secara tidak langsung telah melakukan kesepakatan berupa perjanjian gadai.

Perjanjian accesoir adalah perjanjian yang bersifat tambahan dan dikaitkan dengan perjanjian pokok. ${ }^{6}$ Mariam Darus Badrulzaman juga mengatakan hak accesoir yag artinya adanya hak tertanggung dari adanya suatu perjanjian pokok yaitu perjanjian hutang piutang yang dijaminkan dengan hak tersebut. ${ }^{7}$ Pegadaian dalam menangani barang gadaian milik masyarakat tidak selamanya berjalan dengan lancar. Adakalanya barang gadai milik masyarakat menjadi rusak bahkan hilang.

PT. Pegadaian (Persero) merupakan salah satu lembaga keuangan bukan bank di Indonesia yang memiliki aktifitas membiayai kebutuhan masyarakat, baik bersifat produktif maupun konsumtif, dengan menggunakan hukum gadai. $^{8}$ Tugas utama PT. Pegadaian (Persero)

\footnotetext{
${ }^{6}$ H. Salim HS., Op.Cit, HIm. 30.

7 Mariam Darus Badrulzaman, Hak Tanggungan Sebagai Hak Accesoir, Bandung: Citra Aditya Bhakti, 1991, Hlm. 25.

8 Ade Arthesa dan Edia Handiman, Bank dan Lembaga Keuangan Bukan Bank, Jakarta: PT. Iindeks Kelompok Gramedia, 2006, Hlm. 271.
} 
adalah memberikan pinjaman kepada masyarakat berdasarkan hukum gadai untuk mencegah berkembangnya kegiatan informal dari renternir atau lainnya yang memberikan pinjaman dengan tingkat bunga yang sangat tinggi dan merugikan. ${ }^{9}$ Menurut Peraturan Pemerintah No. 51 Tahun 2011 tentang Perubahan Bentuk Badan Hukum Perusahaan Umum (PERUM) Pegadaian menjadi Perusahaan Perseroan (Persero) mempunyai maksud dan tujuan untuk melakukan usaha di bidang gadai dan fidusia, baik secara konvensional maupun syariah, dan jasa lainnya di bidang keuangan sesuai dengan ketentuan peraturan perundang-undangan terutama untuk masyarakat berpenghasilan menengah ke bawah, usaha mikro, usaha kecil, dan usaha menengah.

Selanjutnya untuk mencapai maksud dan tujuan tersebut, Perusahaan Perseroan (Persero) melaksanakan kegiatan usaha utama yaitu penyaluran pinjaman berdasarkan hukum gadai, termasuk gadai efek, penyaluran pinjaman berdasarkan jaminan fidusia, dan pelayanan jasa titipan, pelayanan jasa taksiran, dan sertifikasi.

Terkait dengan adanya jaminan dengan transaksi kredit antara kreditur dan debitur maka diperlukan adanya suatu lembaga jaminan. Salah satu lembaga jaminan yang digunakan adalah lembaga jaminan fidusia. Jaminan fidusia telah digunakan di Indonesia sejak zaman penjajahan Belanda sebagai suatu bentuk jaminan yang lahir dari yurisprudensi. Bentuk jaminan ini digunakan secara luas dalam transaksi pinjam-meminjam karena proses pembebanannya dianggap sederhana, mudah dan cepat, walau dalam beberapa hal dianggap kurang menjamin adanya kepastian hukum. Dalam perjalanannya, fidusia telah mengalami perkembangan yang cukup berarti misalnya menyangkut kedudukan para pihak.

\footnotetext{
${ }^{9}$ Ibid, Hlm. 247.
}

Fidusia ini sendiri merupakan istilah lama yang sudah dikenal dalam bahasa Indonesia. Menurut Undang-undang Nomor 42 Tahun 1999 tentang Jaminan Fidusia ini disebut juga dengan istilah penyerahan hak milik secara kepercayaan, dari debitur kepada kreditur. ${ }^{10}$ Penyerahan hak milik secara kepercayaan dalam fidusia ini lazim disebut juga dengan penyerahan Constitutum Possesorium (penyerahan dengan melanjutkan penguasaannya). Kontruksi fidusia adalah penyerahan hak milik atas barang-barang debitur kepda kreditur sedang penguasaan fisik atas barang-barang itu tetap pada debitur (Costitutum Posesorium) dengan syarat bahwa apabila debitur melunasi hutangnya, maka kreditur harus mengembalikan hak milik atas barang-barang itu kepada debitor. ${ }^{11}$

Sehubungan dengan penjaminan ini, apa yang harus dilakukan oleh penerima fidusia (kreditur). Apabila pemberi fidusia (debitur) malalaikan kewajibannya atau cidera janji yang berupa lalainya. Pemberi fidusia (debitur), memenuhi kewajibannya pada saat pelunasan utangnya sudah matang untuk ditagih, maka dalam peristiwa seperti itu penerima fidusia (kreditur) bisa melaksanakan eksekusinya atas benda jaminan fidusia. Ketentuan ini didasarkan pada Pasal 29 ayat (1) huruf a Undang-undang Nomor 42 Tahun 1999 tentang Jaminan Fidusia yang berdasarkan ketuhanan maha esa, irah-irah inilah yang memberikan titel eksekutorial yang mensejajarkan kekuatan akta tersebut dengan putusan pengadilan.

Berdasarkan uraian latar belakang masalah tersebut di atas, maka peneliti dalam penelitian ini mengambil judul tentang: "Pengembangan Model Fidusia Terhadap Penitipan Barang Dari Persero Pegadaian Kepada Debitur".

\footnotetext{
10 Martin Roestamy, Hukum Jaminan Fidusia, Jakarta: Percetakan Penebar Swadaya, 2009, Hlm. 48.

11 Munir Fuady, Jaminan Fidusia Revisi Kedua, Jakarta: Citra Aditya Bakti, 2003, Hlm. 10.
} 
Berdasarkan latar belakang masalah yang telah diuraikan di atas, peneliti mengidentifikasi masalah sebagai berikut:

1. Bagaimana pengembangan model fidusia terhadap penitipan barang dari persero pegadaian kepada debitur?

2. Bagaimana eksekusi jaminan fidusia di PT. Pegadaian (Persero) apabila debitur wanprestasi?

\section{METODE PENELITIAN}

Metode penelitian yang digunakan dalam penelitian ini adalah pendekatan yuridis normatif, yaitu hukum dikonsepsikan sebagai norma, kaidah, asas atau dogma-dogma/yurisprudensi.

\section{PEMBAHASAN}

\section{A. PENGEMBANGAN MODEL FIDUSIA TERHADAP PENITIPAN BARANG DARI PERSERO PEGADAIAN KEPADA DEBITUR}

Tingginya tingkat kebutuhan hidup yang harus dipenuhi pada zaman modern ini, merupakan beban yang sangat berat dirasakan oleh sebagian warga masyarakat. Terutama bagi masyarakat yang berpenghasilan rendah, tidak semua kebutuhan mereka dapat terpenuhi. Untuk memenuhi kebutuhan sehari-hari saja mereka masih kekurangan, apalagi untuk memenuhi kebutuhan lainnya seperti biaya pendidikan anak, biaya pengobatan bagi anggota keluarga yang sakit dan biaya untuk mengadakan kegiatan usaha lainnya. Guna memenuhi semua kebutuhankebutuhan tersebut di atas, tentunya masyarakat sangat membutuhkan modal. Kebutuhan akan modal sesungguhnya adalah sesuatu hal yang wajar bagi setiap orang dalam memenuhi berbagai aktifitasnya. Untuk mendapatkan modal biasanya bisa dilakukan melalui berbagai cara. Salah satunya ialah melalui lembaga penyedia jasa perbankan (lembaga kredit) atau melalui pengikatan oleh pihak ketiga melalui tambahan jasa dengan unsur kesepakatan di antara para pihak (umumnya dilakukan oleh lembaga pembiayaan bukan bank).

Pemerintah dalam hal ini berusaha membantu masyarakat dengan menyediakan berbagai fasilitas kredit. Salah satu langkah pemerintah adalah mengembangkan lembaga PT. Pegadaian (Persero). PT. Pegadaian (Persero) ialah BUMN dalam lingkungan Kementerian Keuangan serta merupakan lembaga keuangan bukan bank yang dipimpin oleh seorang Direksi yang berada dan bertanggung jawab kepada Menteri Keuangan.

Dengan Motto "Mengatasi Masalah Tanpa Masalah", merupakan keyakinan PT. Pegadaian (Persero) bahwa setiap orang yang memiliki masalah dalam kehidupan sehariharinya termasuk kegiatan usaha dan kebutuhan seketika (modal kerja dan biaya hidup) mampu diatasi dalam waktu relatif singkat. Adapun maksud dan tujuan adanya PT. Pegadaian (Persero) adalah turut meningkatkan kesejahteraan masyarakat terutama golongan menengah ke bawah melalui penyediaan dana atas dasar hukum gadai, dan jasa di bidang keuangan lainnya berdasarkan ketentuan perundang-undangan yang berlaku. Oleh karena itu dalam rangka mengembangkan usahanya selaku BUMN yang termasuk kategori lembaga keuangan bukan bank, PT. Pegadaian (Persero) juga bertujuan untuk mencari keuntungan dengan mengeluarkan beberapa produk unggulan yang antara lain adalah: Kredit Angsuran Sistem Fidusia (KREASI), Kredit Angsuran Sistem Gadai (KRASIDA), Kredit Cepat dan Aman (KCA), Gadai Syariah (Ar Rahn), Kredit Industri Rumah Tangga (KRISTA), Gadai Efek (Investa), Jasa Penitipan Barang, Jasa Taksiran/Sertifikasi Perhiasan dan Kiriman Uang Cara Instan Cepat dan Aman (KUCICA). Produk-produk tersebut diperuntukkan bagi Pelaku Usaha Mikro Kecil dan Menengah (UMKM) yaitu orang perseorangan atau korporasi bagi perkembangan usahanya. Hal tersebut sesuai dengan misi yang diemban PT. 
Pegadaian (Persero) sebagai Badan Usaha Milik Negara (BUMN).

Salah satu dari produk-produk unggulan tersebut, yang menarik dan memberikan fasilitas kredit yang mudah juga nyaman adalah Kredit Angsuran Sistem Fidusia (KREASI). Produk KREASI ini pada dasarnya berbeda dengan gadai, dimana pada sistem KREASI bahwa benda yang dijadikan jaminan kredit tetap dikuasai oleh pemilik benda semula (debitur), berbeda pada gadai yang mana benda jaminan harus ada pada penerima gadai (kreditur). Dalam hal ini produk KREASI tidak menyulitkan kegiatan usaha debitur, karena barang jaminan tetap dikuasai dan dapat dipergunakan untuk mendukung kegiatan usaha debitur. Hal inilah yang menyebabkan produk KREASI banyak diminati oleh masyarakat karena memberikan kemudahan dan kenyamanan dalam pelaksanaannya. Kredit KREASI adalah salah satu usaha diversifikasi PT. Pegadaian (Persero) yang diharapkan menjadi salah satu produk andalan dalam penyaluran kredit atas fidusia yang menjadi penopang bagi kelangsungan perusahaan. Kredit KREASI ini juga memiliki berbagai keunggulan dibandingkan produk kredit lainnya yaitu pinjaman yang ditawarkan dapat mencapai $70 \%$ dari harga pasar dengan sewa modal yang relatif murah hanya $1 \%$ perbulan flat dan jangka waktu yang fleksibel antara 12 bulan sampai 36 bulan.

Untuk melakukan Kredit KREASI, para pihak antara nasabah dan pihak PT. Pegadaian (Persero) terlebih dahulu mengadakan perjanjian KREASI. Pihakpihak yang mengadakan perjanjian KREASI saling mengikatkan diri untuk suatu obyek tertentu yang dapat mengakibatkan suatu hubungan hukum dari perjanjian KREASI.

Berdasarkan data yang didapat dari PT. Pegadaian (Persero) Cabang Cibinong diketahui, bahwa syarat-syarat yang diperlukan untuk pengajuan Kredit KREASI ialah sebagai berikut:

1. Nasabah dan domisili a. Fotocopy KTP Suami dan Istri 2 rangkap.

b. Fotocopy Kartu Keluarga (KK) dan surat nikah.

c. Surat keterangan domisili dari kelurahan (setelah survey).

d. Fotocopy bukti pembayaran PBB tahun terakhir atau asli pembayaran listrik/ telepon tiga bulan terakhir.

e. Fotocopy bukti tabungan 3 (tiga) bulan terakhir.

f. Pasphoto warna ukuran $3 \times 4$ suamiistri, photo kendaraan, photo tempat usaha, photo tempat tinggal.

2. Kendaraan

a. Fotocopy BPKB, Faktur, STNK, Buku kir (pick-up) dan surat izin trayek yang masih berlaku atas nama pemohon kredit.

b. Cek phisik, keabsahan dan blokir BPKB (setelah survey).

3. Kegiatan Usaha

Fotocopy dokumen usaha (SIUP/SITU/TDP/NPWP) atau surat keterangan lainnya yang masuh berlaku dari kelurahan.

Berdasarkan hasil wawancara dengan Bapak A, untuk dapat memperoleh pinjaman (kredit) KREASI dari PT. Pegadaian (Persero) Cabang Cibinong, masyarakat hanya cukup menyerahkan agunan barang bergerak berupa BPKB kendaraan dengan disertai copy identitas calon nasabah dan surat-surat keterangan lainnya yang dibutuhkan. ${ }^{12}$

Surat-surat keterangan ini adalah menyangkut data mengenai usaha calon debitur. Jadi calon debitur yang diperbolehkan untuk mengikuti kredit KREASI ini adalah mereka perorangan/badan hukum yang memiliki usaha baik itu dalam skala besar maupun kecil. Kemudian petugas penaksir akan menentukan nilai taksiran barang bergerak tersebut yang akan dijadikan sebagai patokan perhitungan plafon uang pinjaman yang dapat diberikan. Pegadaian (Persero).

12 Hasil wawancara dengan Bapak A, selaku debitur PT. Pegadaian (Persero) Cabang Cibinong, pada tanggal 2 April 2019. 
Maksimum uang pinjaman yang bisa diberikan ialah sebesar 90\% dari nilai taksiran barang.

Dalam melakukan pengajuan Kredit KREASI pada PT. Pegadaian (Persero), ada beberapa tahapan yang perlu diketahui oleh debitur. Hal yang terpenting untuk diperhatikan adalah bahwa debitur harus terlebih dahulu melengkapi persyaratan sebelum mengajukan permohonan kredit dengan sistem KREASI pada PT. Pegadaian (Persero). Jika seluruh syarat sebagai pemohon dalam ketentuan ini dianggap memenuhi oleh pihak PT. Pegadaian (Persero) tentang layak atau tidak layaknya kredit tersebut diterima oleh nasabah, maka selanjutnya nasabah diharuskan untuk mengikuti pula prosedur pemberian kredit KREASI yang sudah ditetapkan oleh pihak PT. Pegadaian (Persero).

Dalam Perjanjian Kredit Angsuran Sistem Fidusia (KREASI) ini terdapat 2 (dua) perjanjian, yaitu perjanjian pokok dan perjanjian pelengkap. Perjanjian pertama merupakan perjanjian hutang piutang sebagai perjanjian pokoknya. Perjanjian kedua merupakan perjanjian pengalihan hak kepemilikan barang jaminan atas dasar kepercayaan (fidusia) yang merupakan perjanjian pelengkap (accessoir) dari perjanjian pokok.

Perjanjian hutang piutang adalah perjanjian pinjam meminjam baik berupa uang maupun barang. Perjanjian hutang piutang ini dapat dilakukan antara orang dengan orang pribadi atau antara seseorang dengan suatu badan atau lembaga yang berbentuk badan hukum, misalnya antara seorang nasabah dengan PT. Pegadaian (Persero) mengenai Perjanjian KREASI. Perjanjian ini terjadi sejak adanya kata sepakat antara debitur dan kreditur. Sejak kesepakatan itu maka pihak debitur wajib menyerahkan agunan yang telah disetujui untuk dijaminkan atas hutangnya. Selanjutnya kreditur wajib memberikan sejumlah uang kepada debitur sesuai dengan yang diperjanjikan.

\section{B. EKSEKUSI JAMINAN FIDUSIA DI PT. PEGADAIAN (PERSERO) APABILA DEBITUR WANPRESTASI}

Prestasi adalah sesuatu yang wajib dipenuhi oleh debitur dalam setiap perikatan. Prestasi merupakan isi perikatan. Prestasi dapat berupa memberikan sesuatu, berbuat sesuatu, atau tidak berbuat sesuatu. Apabila debitur tidak memenuhi prestasi sebagaimana ditentukan dalam perjanjian, maka debitur dapat dikatakan telah melakukan wanprestasi.

Wanprestasi berasal dari bahasa Belanda yang berarti prestasi buruk. Wanprestasi dapat berupa 4 (empat) macam yaitu: ${ }^{13}$

1) Tidak melakukan apa yang disanggupi akan dilakukannya.

2) Melaksanakan apa yang diperjanjikannya, akan tetapi tidak sebagaimana diperjanjikan.

3) Melakukan apa yang diperjanjikannya tetapi terlambat.

4) Melakukan sesuatu yang menurut perjanjian tidak dapat dilakukannya.

Dalam pelaksanaan perjanjian ada kemungkinan debitur tidak bisa memenuhi apa yang menjadi kewajibannya. Tidak memenuhi kewajiban atau prestasi tersebut biasanya bersifat sementara yaitu berupa keterlambatan dalam pembayaran angsuran yang harus dibayar setiap bulannya. Hal itu kemungkinan terjadi karena debitur lupa tanggal jatuh tempo pembayaran ataupun sengaja menunggak pembayaran karena kesulitan keuangan.

Apabila debitur terlambat dalam membayar angsuran, maka kreditur akan memberikan teguran atau peringatan atau somasi kepada debitur agar segera memenuhi kewajibannya. Akibat atas keterlambatan debitur membayar angsuran, maka kreditur akan meminta ganti rugi kepada debitur.

13 R. Subekti, Hukum Perjanjian, Jakarta : PT. Intermassa, 1987, Hlm. 45. 
Berdasarkan ketentuan Pasal 1246 KUHPerdata, dengan adanya keterlambatan dalam pembayaran angsuran yang dilakukan oleh debitur, maka kreditur bisa menuntut kerugian berupa denda yang berupa bunga, biaya-biaya yang telah dikeluarkan kreditur, keuntungankeuntungan yang semestinya diperoleh pihak kreditur. Biasanya dalam perjanjian yang dibuat antara kreditur dengan debitur dalam salah satu pasalnya memuat mengenai pengenaan denda untuk tiap keterlambatan pembayaran angsuran yang dilakukan oleh debitur.

Apabila debitur mengabaikan peringatan kreditur sampai dengan 3 (tiga) kali berturut-turut, maka yang dilakukan kreditur adalah melakukan eksekusi atas benda yang menjadi obyek jaminan fidusia.

Dalam pelaksanaan eksekusi ini pemberi fidusia wajib menyerahkan benda yang menjadi obyek jaminan fidusia. Hal ini sesuai dengan Pasal 30 Undang-undang No. 42 Tahun 1999 tentang Jaminan Fidusia. Dalam hal pemberi fidusia tidak menyerahkan benda yang menjadi obyek jaminan fidusia pada waktu eksekusi dilaksanakan, penerima fidusia berhak mengambil benda yang menjadi obyek jaminan fidusia dan apabila perlu dapat meminta bantuan pihak yang berwenang.

Dasar untuk melaksanakan eksekusi adalah karena Akta Jaminan Fidusia yang didaftarkan ke Kantor Pendaftaran Fidusia oleh PT. Pegadaian (Persero) Cabang Cibinong, dan setelah pendaftaran tersebut PT. Pegadaian (Persero) Cabang Cibinong memperoleh Sertifikat Jaminan Fidusia.

Dalam Sertifikat Jaminan Fidusia dicantumkan irah-irah "DEMI KEADILAN BERDASARKAN KETUHANAN YANG MAHA ESA“, sehingga mempunyai kekuatan yang sama dengan suatu putusan pengadilan yang telah memperoleh kekuatan hukum yang tetap. Proses eksekusi suatu putusan pengadilan yang telah memperoleh kekuatan hukum yang pasti atau bersifat serta merta termasuk proses eksekusi Sertifikat Jaminan Fidusia dengan irah-irah
"DEMI KEADILAN BERDASARKAN KETUHANAN YANG MAHA ESA“ mempunyai 3 (tiga) tahapan, yaitu: ${ }^{14}$

a. Tahap peneguran, pada tahap ini debitur yang cidera janji diperingatkan untuk memenuhi kewajiban membayar hutangnya dalam jangka waktu 8 (delapan) hari setelah diberi peneguran.

b. Tahap sita eksekusi, dalam hal debiturnya dalam jangka waktu 8 (delapan) hari tersebut di atas tidak juga memenuhi kewajibannya membayar hutang pada kreditur, maka pemohon eksekusi mohon kepada ketua pengadilan yang berwenang untuk melakukan sita eksekusi.

c. Tahap pelelangan, dalam hal setelah dilakukan sita eksekusi terhadap obyek jaminan fidusia debitur tetap tidak membayar hutangnya, maka atas permohonan pemohon eksekusi (kreditur pemegang sertifikat fidusia) pengadilan yang berwenang melakukan pelelangan obyek jaminan fidusia. Dan hasil penjualan lelang tersebut setelah dikurangi biaya lelang dan biaya lain-lain diserahkan kepada kreditur pemohon eksekusi. Bila ada sisanya diserahkan kembali kepada debitur.

Dasar hukum pelaksanaan eksekusi adalah Pasal 15 dan Pasal 29 Undangundang Nomor 42 Tahun 1999 tentang Jaminan Fidusia.

Dalam Pasal 29 disebutkan bahwa: apabila debitur atau pemberi fidusia cidera janji, eksekusi terhadap benda yang menjadi obyek jaminan fidusia dapat dilakukan dengan cara:

a. Pelaksanaan title eksekutorial.

Dengan adanya irah-irah "DEMI KEADILAN BERDASARKAN KETUHANAN YANG MAHA ESA“

14 Elijana Tansah, Aspek Hukum Objek Jaminan Fidusia Menurut Undang-undang Nomor 4 Tahun 1996 (Hak Tanggungan) dan Undang-undang Nomor 42 Tahun 1999 (Fidusia), Makalah Pada Seminar Sosialisasi Undang-undang Nomor 42 Tahun 1999 tentang Fidusia, 2015, HIm. 6-7. 
sehingga Sertifikat Jaminan Fidusia mempunyai kekuatan yang sama dengan putusan pengadilan yang telah memperoleh kekuatan hukum tetap.

Berdasarkan penjelasan Pasal 15 ayat (2) Undang-undang Nomor 42 Tahun 1999 tentang Jaminan Fidusia yang dimaksud dengan "kekuatan eksekutorial" adalah langsung dapat dilaksanakan tanpa melalui pengadilan dan bersifat final serta mengikat para pihak untuk melaksanakan putusan tersebut".

Maka dengan adanya title eksekutorial ini, baik PT. Pegadaian (Persero) Cabang Cibinong sebagai kreditur penerima fidusia dapat langsung melakukan eksekusi tanpa didahului dengan permohonan eksekusi melalui peradilan karena irah-irah yang terdapat dalam Sertifikat Jaminan Fidusia sama dengan putusan pengadilan yang berkekuatan hukum tetap.

Namun dalam praktik ternyata untuk dapat melakukan title eksekutorial perlu dilakukan fiat eksekusi. Fiat eksekusi adalah eksekusi atas sebuah akta seperti mengeksekusi suatu putusan pengadilan yang telah berkekuatan hukum tetap, yaitu dengan cara meminta "fiat" dari ketua pengadilan dimana penerima fidusia memohon penetapan dari ketua pengadilan untuk melakukan eksekusi.

b. Penjualan benda yang menjadi obyek jaminan fidusia atas kekuasaan penerima fidusia sendiri melalui pelelangan umum serta mengambil pelunasan piutangnya dari hasil penjualan.

Apabila debitur cidera janji, penerima fidusia mempunyai hak menjual benda obyek jaminan fidusia atas kekuasaannya sendiri. Penjualan dengan cara ini dikenal dengan nama lembaga parate eksekusi dan diharuskan dijual melalui pelelangan umum. Dengan demikian parate eksekusi kurang lebih adalah kewenangan yang diberikan (oleh Undang-undang atau putusan pengadilan) kepada salah satu pihak untuk melaksanakan sendiri secara paksa isi perjanjian manakala pihak yang lainnya wanprestasi. ${ }^{15}$

c. Penjualan yang dilakukan di bawah tangan yang dilakukan berdasarkan kesepakatan pihak pemberi dan penerima fidusia, jika dengan cara demikian dapat diperoleh harga tertinggi yang menguntungkan para pihak.

Ada 3 (tiga) persyaratan untuk dapat melakukan penjualan di bawah tangan, yaitu:

1) Kesepakatan pemberi dan penerima fidusia. Syarat ini diperkirakan akan berpusat pada soal harga dan biaya yang menguntungkan para pihak.

2) Setelah lewat waktu 1 (satu) bulan sejak diberitahukan secara tertulis oleh pemberi dan atau penerima fidusia kepada pihak-pihak yang berkepentingan.

3) Diumumkan sedikitnya dalam 2 (dua) surat kabar yang beredar di daerah yang bersangkutan.

Eksekusi ini merupakan salah satu hak dari kreditur. Dasar dari pernyataan ini adalah karena maksud pemberian hak fidusia adalah untuk memberikan jaminan bagi kreditor untuk pelunasan piutangnya. Apabila debitor wanprestasi, maka debitur berhak untuk menguasai dan selanjutnya menjual benda jaminan fidusia dengan maksud untuk mengambil pelunasan piutang pokok, bunga dan biaya dari hasil pendapatan lelang.

Dalam hal ini terjadi perbedaan pendapat antara PT. Pegadaian (Persero) dengan KP2LN untuk pelaksanaan eksekusi jaminan fidusia di PT. Pegadaian (Persero). PT. Pegadaian (Persero) berpendapat bahwa PT. Pegadaian (Persero)

\footnotetext{
15 Bachtiar Sibarani, Aspek Hukum Eksekusi Jaminan Fidusia, Makalah Pada Seminar Sosialisasi Undangundang Nomor 42 Tahun 1999 tentang Fidusia, 2015, Hlm. 23.
} 
mempunyai wewenang khusus berdasarkan Aturan Dasar Pegadaian untuk melakukan lelang sendiri di PT. Pegadaian (Persero). Sedangkan KP2LN berpendapat bahwa berdasarkan Pasal 15 ayat (3) Undang-undang Nomor 42 Tahun 1999 tentang Jaminan Fidusia lelang jaminan fidusia harus dilaksanakan oleh KP2LN.

Dalam hal ini penulis sependapat dengan KP2LN karena Aturan Dasar Pegadaian hanya berlaku untuk jaminan gadai saja, dan bukan untuk jaminan fidusia sehingga dasar hukum untuk eksekusinya kurang kuat apabila PT. Pegadaian (Persero) mengacu pada Aturan Dasar Pegadaian sebagai dasar hukumnya.

Oleh karena tidak semua jaminan fidusia didaftarkan, maka pengikatan jaminan fidusia di PT. Pegadaian (Persero) belum dilakukan dengan sempurna karena adanya hambatan masalah biaya yang tinggi sehingga pelaksanaan eksekusi jaminan fidusia di PT. Pegadaian (Persero) banyak dilakukan melalui penjualan di bawah tangan. Hal ini dapat dimaklumi karena biaya yang sangat tinggi sedangkan kredit di PT. Pegadaian (Persero) sangat kecil, sehingga penjualan di bawah tangan terjadi. Sebaliknya kalau pengikatan jaminan fidusia dilakukan sempurna dengan Sertifikat Jaminan Fidusia, sehingga ada kemungkinan akan menyerahkan pelaksanaan eksekusi jaminan fidusia tersebut ke KP2LN.

Apabila hasil dari eksekusi yang dilakukan oleh kreditur tidak dapat memenuhi kredit (hutang) yang harus dilunasi oleh debitur, maka debitur harus melunasi kekurangan tersebut. Jika melebihi dari jumlah kredit (hutang) yang harus dilunasi oleh debitur, maka kreditur harus mengembalikan kelebihan tersebut kepada debitur.

Untuk perjanjian jaminan fidusia yang dibuat di bawah tangan, Akta Jaminan Fidusia tersebut tidak dapat didaftarkan ke Kantor Pendaftaran Fidusia. Dengan demikian, tidak menyebabkan lahirnya jaminan fidusia yang menimbulkan konsekuensi yaitu kreditur hanya berkedudukan sebagai kreditur konkuren dan kreditur tersebut tidak mempunyai hak preference (hak untuk didahulukan dalam pelunasan piutang). Jika debitur wanprestasi, yang dilakukan oleh kreditur adalah dengan mengajukan gugatan ke pengadilan.

\section{KESIMPULAN}

Berdasarkan hasil penelitian di atas, penulis dapat mengambil kesimpulan sebagai berikut:

1. Pengembangan model fidusia terhadap penitipan barang dari persero pegadaian kepada debitur, yaitu dengan Kredit Angsuran Sistem Fidusia (KREASI), dimana pada fasilitas kredit tersebut tunduk pada ketentuan yang berlaku pada hukum fidusia. Debitur yang membutuhkan dana tidak menyerahkan benda yang dijadikan agunan kepada PT. Pegadaian (Persero) sebagai kreditur.

2. Eksekusi jaminan fidusia di PT. Pegadaian (Persero) apabila debitur wanprestasi, dalam pelaksanaan eksekusi jaminan fidusia di PT. Pegadaian (Persero) ada perbedaan pendapat antara PT. Pegadaian (Persero) dengan Kantor Pelayanan Piutang dan Lelang Negara (KP2LN). PT. Pegadaian (Persero) menyatakan bahwa eksekusi jaminan fidusia dilakukan oleh PT. Pegadaian (Persero) sendiri dengan mengacu pada Aturan Dasar Pegadaian. Sedangkan Kantor Pelayanan Piutang dan Lelang Negara (KP2LN) berpendapat bahwa yang berwenang untuk melaksanakan eksekusi jaminan fidusia adalah (KP2LN) dengan mengacu pada Undang-undang Fidusia. Dalam hal ini penulis lebih sependapat dengan KP2LN karena dasar hukum KP2LN yaitu Undang-undang Fidusia lebih kuat dibandingkan dengan Aturan Dasar Pegadaian. Selain itu, aturan dasar pegadaian hanya berlaku untuk jaminan gadai saja, dan bukan untuk jaminan fidusia. 


\section{SARAN}

1. Mengingat fasilitas KREASI ini belum lama diselenggarakan oleh PT. Pegadaian (Persero), sehingga masih banyak hal-hal yang perlu diperhatikan dalam rangka memberikan pelayanan kepada masyarakat dengan tidak mengesampingkan prinsip kehatihatian.
2. Kepada Kantor Pendaftaran Fidusia sebaiknya biaya pendaftaran akta jaminan fidusia jangan terlalu besar, karena dengan biaya yang ringan tentunya akan membantu pihak kreditur agar bisa membuat akta jaminan fidusia secara notaril dan dapat mendaftarkannya ke Kantor Pendaftaran Fidusia.

\section{DAFTAR PUSTAKA}

\section{A. Buku:}

Abdul Kadir Muhammad, Hukum Perdata Indonesia, Bandung: PT. Citra Aditya Bakti, 2000.

Ade Arthesa dan Edia Handiman, Bank dan Lembaga Keuangan Bukan Bank, Jakarta: PT. Iindeks Kelompok Gramedia, 2006.

Bachtiar Sibarani, Aspek Hukum Eksekusi Jaminan Fidusia, Makalah Pada Seminar Sosialisasi Undang-undang Nomor 42 Tahun 1999 tentang Fidusia, 2015.

Edy Sasmito, dkk, Pegadaian dan Rakyat Kecil, Bogor: IPB Pers, 2010.

Elijana Tansah, Aspek Hukum Objek Jaminan Fidusia Menurut Undang-undang Nomor 4 Tahun 1996 (Hak Tanggungan) dan Undang-undang Nomor 42 Tahun 1999 (Fidusia), Makalah Pada Seminar Sosialisasi Undang-undang Nomor 42 Tahun 1999 tentang Fidusia, 2015.

Gatot Supramono, Perjanjian Utang Piutang, Jakarta: Kencana Prenada Media Group, 2013.

Gunawan Widjaja dan Ahmad Yani, Jaminan Fidusia, Jakarta: PT. Raja Grafindo Persada, 2000.

H. Salim HS., Perkembangan Hukum Jaminan di Indonesia, Cet. 6, Jakarta: Rajawali Pers, 2012.

I Ketut Artadi dan I Dewa Nym. Rai Asmara Putra, Implementasi Ketentuan-ketentuan Hukum Perjanjian Kedalam Perancangan Kontrak, Denpasar: Udayana University Press, 2010.

Mariam Darus Badrulzaman, Hak Tanggungan Sebagai Hak Accesoir, Bandung: Citra Aditya Bhakti, 1991.

Martin Roestamy, Hukum Jaminan Fidusia, Jakarta: Percetakan Penebar Swadaya, 2009.

Munir Fuady, Jaminan Fidusia Revisi Kedua, Jakarta: Citra Aditya Bakti, 2003. 
Purwahid Patrik dan Kashadi, Hukum Jaminan Edisi Revisi Dengan UUHT, Pusat Studi Hukum Perdata dan Pembangunan Fakultas Hukum Universitas Diponegoro, Semarang, 1993.

R. Subekti, Hukum Perjanjian, Jakarta : PT. Intermassa, 1987.

Rachmadi Usman, Hukum Jaminan Keperdataan, Ed-1, Cet-2, Jakarta: Sinar Grafika, 2009.

\section{B. Peraturan Perundang-undangan}

Undang-undang Dasar Negara Republik Indonesia Tahun 1945.

Kitab Undang-undang Hukum Perdata.

Undang-undang Nomor 42 Tahun 1999 tentang Jaminan Fidusia.

Peraturan Pemerintah Nomor 51 Tahun 2011 tentang Perubahan Bentuk Badan Hukum Perusahaan Umum (Perum) Pegadaian Menjadi Perusahaan Perseroan (Persero).

\section{Jurnal Hukum}

Abraham Yazdi Martin dan I Kadel Vemil, Kepastian Hukum Jaminan Alat Berat Sebagai Objek Fidusia, Jurnal Ilmiah, Living Law, Volume 7, Nomor 1, Januari 2015.

Ahmad Yani dan Agus Sadikin, Efektifitas Pemberian Kredit Tanpa Agunan Pada Bank Umum, Jurnal Ilmiah, Living Law, Volume 7, Nomor 2, Oktober 2015.

Inge Dwisvimiar, “Keadilan Dalam Perspektif Filsafat Ilmu Hukum”, Jurnal Dinamika Hukum, Vol. 11, 2017.

Martin Roestamy dan Adang Purnama, Efektivitas Penyelesaian Sengketa Fidusia Terhadap Penyerahan Jaminan Fidusia Kredit Mikro, Jurnal Ilmiah Living Law, Volume 8, Nomor 1, Januari 2016. 